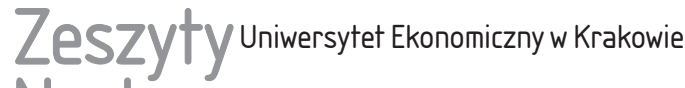 Naukowe
}

9(969)

ISSN 1898-6447

Zesz. Nauk. UEK, 2017: 9(969): 49-68 DOI: 10.15678/ZNUEK.2017.0969.0904

Katarzyna Stabryła-Chudzio

\section{Struktura wydatków unijnych po 2020 roku w aspekcie wyzwań integracyjnych}

\section{Streszczenie}

W artykule przedstawiono najnowsze koncepcje dotyczące modeli integracji europejskiej. Szczególną uwagę zwrócono na kwestie finansowe, tj. możliwe kierunki wydatkowania środków z budżetu Unii Europejskiej po 2020 r. pod kątem ewentualnych nowych, wspólnych strategii gospodarczych, społecznych i obronnych. Rozważania prowadzono, opierając się na metodzie scenariuszowej, w której najważniejszym elementem było pytanie dotyczące realności wprowadzenia w Unii Europejskiej federalizmu fiskalnego, a co za tym idzie, analizie poddano również polityczny aspekt ugrupowania, czyli możliwe zmiany o charakterze instytucjonalnym.

Słowa kluczowe: wydatki unijne, wieloletnie ramy finansowe, integracja europejska, Brexit.

Klasyfikacja JEL: F36, F37, G28, H77, H87.

\section{Wprowadzenie}

Wobec wyzwań o charakterze gospodarczo-społecznym (funkcjonowanie państw członkowskich w warunkach pokryzysowych z wysoką stopą bezrobocia wśród osób młodych do 25 roku życia, brak jednoznacznego scenariusza funkcjonowania jednolitego rynku wewnętrznego po wystąpieniu z UE Wielkiej Brytanii,

Katarzyna Stabryła-Chudzio, Uniwersytet Ekonomiczny w Krakowie, Wydział Finansów i Prawa, Katedra Finansów, ul. Rakowicka 27, 31-510 Kraków, e-mail: stabrylk@uek.krakow.pl 
problemy demograficzne, tj. starzenie się społeczeństwa, tendencje protekcjonistyczne, renegocjacje umów handlowych, zachowanie konkurencyjności wobec krajów trzecich, konieczność ograniczenia emisji gazów cieplarnianych) oraz o charakterze polityczno-obronnym (coraz większa rola partii populistycznych o nastawieniu antyunijnym, kryzys imigracyjny, zagrożenie terrorystyczne, działania wojenne w Afryce i na Bliskim Wschodzie, zachowanie Rosji i Stanów Zjednoczonych) pojawia się coraz więcej dokumentów traktujących o przyszłości integracji europejskiej. Do dokumentów tych można zaliczyć pięć scenariuszy przedstawionych w marcu 2017 r. przez Komisję Europejską.

Raport Komisji Europejskiej został poddany analizie podczas obrad Rady Europejskiej, które miały miejsce 25 marca 2017 r. z okazji 60-lecia traktatów rzymskich. W efekcie należy postawić pytanie o możliwe kierunki integracji europejskiej w ciągu najbliższych dziesięciu lat (tj. ewentualne zmiany w wieloletnich ramach finansowych). Celem artykułu jest próba ukazania kierunków wydatków pochodzących z budżetu Unii Europejskiej po zakończeniu obecnego okresu programowania. Ze względu na szeroki obszar badawczy w niniejszym artykule rozważania skoncentrowano wokół kwestii finansowych, tj. kierunków wydatkowania środków z budżetu UE po 2020 r. pod kątem ewentualnych nowych, wspólnych strategii gospodarczych, społecznych i obronnych. Rozważania prowadzono w oparciu o metodę scenariuszową, w której najważniejszy element stanowiło pytanie o realność wprowadzenia w Unii Europejskiej federalizmu fiskalnego lub działań skutkujących stopniową dezintegracją finansową, a co za tym idzie, analizie poddano również polityczny aspekt ugrupowania, czyli możliwe zmiany o charakterze instytucjonalnym.

Podstawą rozważań były wybrane warianty przyjęte przez Komisję Europejską [Biała ksiegga... 2017] przed szczytem w Rzymie w marcu 2017 r., tj.:

1) utrzymanie status quo, czyli wstrzymanie się od istotnych zmian w funkcjonowaniu ugrupowania (kontynuacja dotychczasowych działań),

2) ograniczenie Unii do swobody przepływu towarów i kapitału,

3) wprowadzenie w szerszym zakresie Europy wielu prędkości,

4) ograniczenie działań Unii przy jednoczesnym wzroście ich efektywności,

5) oddanie istotnych uprawnień władz narodowych na rzecz instytucji unijnych, co prowadziłoby do powstania formy federacyjnej.

\section{Teoretyczne propozycje zmian w finansach Unii Europejskiej}

Rozpoczęcie procedury wyjścia Wielkiej Brytanii z Unii Europejskiej 29 marca 2017 r. wpisuje się w dyskusję nad zmianą funkcjonowania ugrupowania w różnych aspektach, w tym w kontekście finansowym, czyli jak zmienią się 
źródła dochodów, a także czy po likwidacji rabatu brytyjskiego pozostaną inne mechanizmy korekcyjne oraz, co stanowi temat niniejszego opracowania, jak ukształtują się wydatki wspólnotowe.

Zgodnie z procedurą zapisaną w art. 50 Traktatu o Unii Europejskiej rezygnacja z członkostwa przez Wielką Brytanię w ciągu dwóch lat będzie pociągać za sobą następujące możliwe konsekwencje:

- utrzymanie poziomu wydatków unijnych po 2020 r. będzie możliwe jedynie przy wzroście składek pozostałych krajów członkowskich (głównie Niemiec, Francji, Włoch i Hiszpanii) zakładając, że wpłaty Wielkiej Brytanii do budżetu UE (po odjęciu rabatu) zostaną podzielone między państwa członkowskie według ich udziału w DNB unijnym (tabela 1) ${ }^{1}$,

- planowany przegląd struktury budżetu unijnego w 2017 r. może spowodować ograniczenie wydatków na politykę spójności przy utrzymaniu wysokości składek na niezmienionym poziomie,

- również w 2017 r. może zostać podjęta decyzja o wprowadzeniu uogólnionego mechanizmu korekcyjnego przy jednoczesnej rezygnacji z rabatu brytyjskiego oraz innych uznaniowych obniżek.

Przykładem propozycji dotyczących przyszłości integracji w odpowiedzi na referendum w Wielkiej Brytanii może być wystąpienie ministrów spraw zagranicznych Francji i Niemiec, J.M. Ayraulta i F.W. Steinmeiera, którzy zaraz po referendum w Wielkiej Brytanii przedstawili dokument pn. „A strong Europe in a world of uncertainties" (http://static.presspublica.pl/red/rp/pdf/DokumentUE.pdf, data dostępu: 1.09.2016). W planie podkreślono konieczność dalszej współpracy w zakresie polityki bezpieczeństwa i obronności, co może stanowić zaskoczenie nie tyle w związku z bieżącą sytuacją geopolityczną w Europie i na świecie, ile z powodu dotychczasowego sprzeciwu państw członkowskich Unii Europejskiej wobec prowadzenia działań o charakterze ponadnarodowym ${ }^{2}$. W dokumencie

${ }^{1}$ W ostatecznych symulacyjnych obliczeniach wykluczono rabat brytyjski z wpłat krajów członkowskich, jak również podzielono między wszystkich członków dotychczasową składkę Zjednoczonego Królestwa (również odejmując rabat). W efekcie ostateczna wartość dochodów zmniejszyła się o wielkość rabatu, tj. z 142,3 mld EUR do 137,0 mld EUR, co nie jest istotnym błędem, biorąc pod uwagę, że po stronie wydatkowej także trzeba byłoby odjąć wydatki na rzecz Wielkiej Brytanii zbliżone wartością do wielkości rabatu.

${ }^{2}$ Nastawienie krajów członkowskich ulega jednak pewnym zmianom, a dodatkowo w orędziu o stanie Unii Europejskiej wygłoszonym przez J.C. Junckera we wrześniu 2016 r. pojawił się temat utworzenia wspólnego sztabu generalnego dla misji cywilnych i wojskowych, ściślejszej kooperacji oraz częstszego wykorzystania wspólnych sił wojskowych we współpracy z NATO. Poprawa potencjału obronnego Unii jako całości lub przynajmniej zainteresowanych państw, w tym zwiększenie wydatków na wykorzystanie nowoczesnych technologii w przemyśle obronnym i badania w tym zakresie, może zostać w przyszłości sfinansowana z Europejskiego Funduszu Obronnego (http:// ec.europa.eu/priorities/state-union-2016_pl, data dostępu: 20.09.2016). W wystąpieniu przewodni- 
zaproponowano stworzenie sił szybkiego reagowania finansowanych ze wspólnych środków, nie określono jednak wyraźnie, czy fundusze będą gromadzone w budżecie unijnym. Środki te mają pokrywać zakup sprzętu, wydatki na badania w zakresie obronności i wykorzystanie nowych technologii. Autorzy postulują spójność działań dotyczących możliwości obronnych i wydatków w tym zakresie dyskutowaną co roku w czasie tzw. europejskiego semestru dotyczącego możliwości obronnych (European semester on defence capabilities). Ponadto podkreślono konieczność przeciwdziałania terroryzmowi i walki z nim, ściślejszej integracji w zakresie bezpieczeństwa wewnętrznego oraz większego wsparcia dla ochrony ludności w razie wystąpienia sytuacji kryzysowych.

Zwrócono również uwagę na politykę imigracyjną i azylową, przy czym nie podano nowych rozwiązań w zakresie napływu dużej liczby imigrantów na teren państw członkowskich, a jedynie powtórzono znane już postulaty dotyczące utworzenia wspólnej straży przybrzeżnej i ochrony granic zewnętrznych Unii z użyciem służb międzynarodowych, a także pomocy uchodźcom przede wszystkim na terenach jak najbliżej ich miejsca zamieszkania. W tym zakresie idea integracji europejskiej została zachwiana nie tyle z powodu znalezienia się na terenie Unii uchodźców wojennych i imigrantów ekonomicznych, ile z braku wspólnej strategii działania, pozostawienia początkowo krajów południa Europy z koniecznością wewnętrznego rozwiązania problemu, a następnie niezaakceptowanymi pomysłami dotyczącymi tzw. kwot imigracyjnych. W rezultacie kryzys imigracyjny stał się swoistym testem dla wiarygodności idei dalszego pogłębiania integracji europejskiej, który pokazał istotną polaryzację poglądów przedstawicieli poszczególnych państw, konieczność ściślejszej współpracy z Turcją ze świadomością uzależnienia planu Unii Europejskiej od decyzji Ankary i wreszcie stał się kolejnym argumentem przeciwko integracji dla partii antyunijnych.

Ostatni postulat traktuje o konwergencji gospodarek krajów członkowskich w zakresie osiągnięcia trwałego wzrostu gospodarczego i o dokończeniu budowy Unii Gospodarczej i Walutowej. Ministrowie, w imieniu swoich krajów, zadeklarowali dalsze prace nad wspólnymi rozwiązaniami dotyczącymi opodatkowania osób prawnych i innych inicjatyw pozwalających na przyciągnięcie inwestycji zagranicznych. Podkreślono, że inwestycje pobudzające wzrost gospodarczy powinny ulec zwiększeniu, w czym pomaga finansowanie za pomocą Europejskiego Funduszu Inwestycji Strategicznych. W sposób bardzo zdawkowy autorzy proponują utworzenie dla państw strefy euro instytucji parlamentarnej składającej się z członków Parlamentu Europejskiego i parlamentów narodowych, przed którą będzie odpowiedzialna Eurogrupa i jej przewodniczący. Działania nowo powstałego parlamentu miałyby dotyczyć polityki fiskalnej i makroekonomicznej.

czącego Komisji Europejskiej można zauważyć wyraźne podobieństwa do idei głoszonych przez ministrów spraw zagranicznych Francji i Niemiec. 


\begin{tabular}{|c|c|c|c|c|c|c|c|c|c|c|c|c|c|c|c|c|c|}
\hline 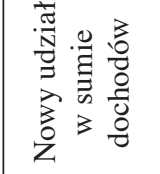 & $\wedge$ & \begin{tabular}{l|l}
$\mathbb{B}_{i}$ & $\stackrel{2}{+}$
\end{tabular} & 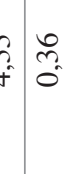 & $\stackrel{n}{2}$ & $\stackrel{ \pm}{0}$ & $\stackrel{\widehat{A}}{-}$ & . & $\overline{0}$ & 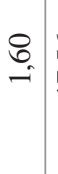 & : & & & & 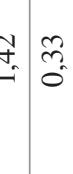 & 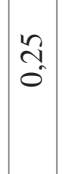 & 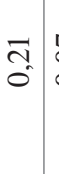 & O. \\
\hline 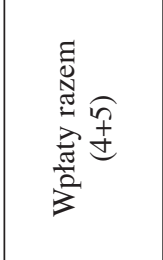 & & 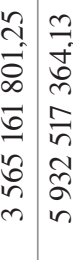 & 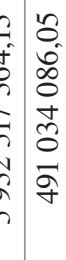 & $\begin{array}{l}1 \\
2 \\
0 \\
2 \\
0 \\
0 \\
1 \\
+ \\
\infty \\
+\end{array}$ & $\begin{array}{l}5 \\
0 \\
0 \\
0 \\
0 \\
5 \\
6 \\
0 \\
\infty \\
0\end{array}$ & 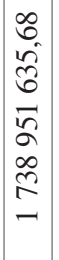 & 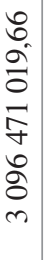 & 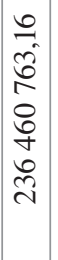 & 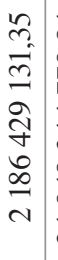 & 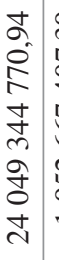 & 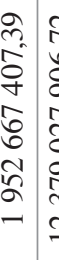 & 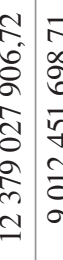 & 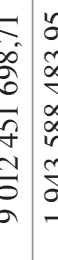 & 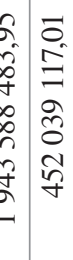 & 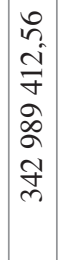 & 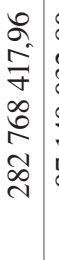 & \\
\hline 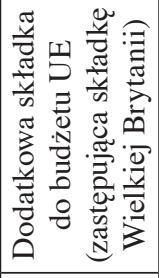 & 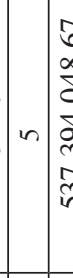 & 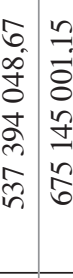 & 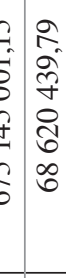 & $\begin{array}{l}2 \\
\hat{0} \\
0 \\
0 \\
\hat{2} \\
i \\
0 \\
0\end{array}$ & 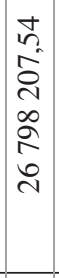 & 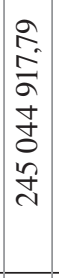 & 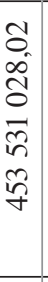 & $\begin{array}{l}0 \\
2 \\
+1 \\
\infty \\
0 \\
d \\
2 \\
\infty \\
m\end{array}$ & 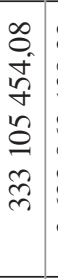 & 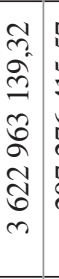 & 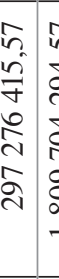 & 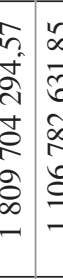 & 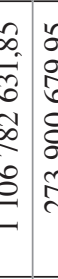 & 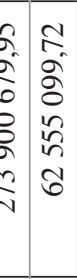 & 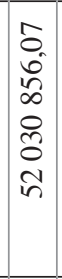 & 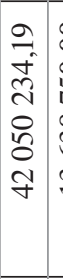 & $\begin{array}{l}8 \\
0 \\
0 \\
2 \\
\infty \\
0 \\
0 \\
0\end{array}$ \\
\hline 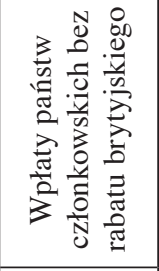 & 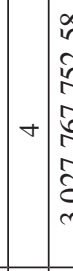 & 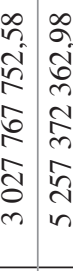 & 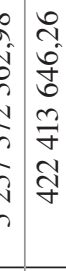 & $\begin{array}{l}n \\
2 \\
20 \\
0 \\
5 \\
2 \\
0 \\
7\end{array}$ & 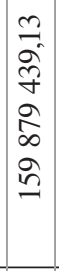 & 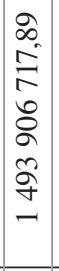 & 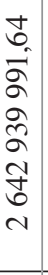 & $\begin{array}{l}q \\
q \\
\infty \\
\infty \\
\infty \\
i \\
i \\
\hat{i} \\
i \\
i\end{array}$ & 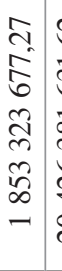 & 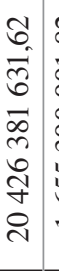 & 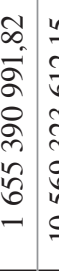 & 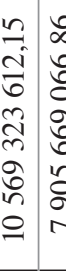 & 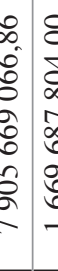 & 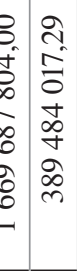 & 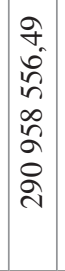 & 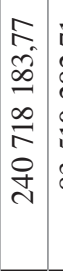 & 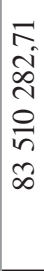 \\
\hline 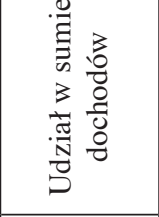 & $m$ & 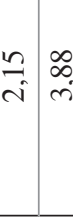 & \begin{tabular}{l}
$0_{0}^{\circ}$ \\
\hdashline \\
$i$
\end{tabular} & $\overrightarrow{\underline{n}}$ & $\stackrel{7}{0}$ & $\cong$ & $\stackrel{\infty}{\stackrel{2}{二}}$ & $\frac{n}{0}$ & ले & 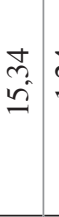 & $\stackrel{\Xi}{\underset{\Xi}{-}}$ & 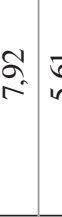 & $\begin{array}{cc}6 & 4 \\
i & \end{array}$ & $\begin{array}{l}2 \\
= \\
=\end{array}$ & $\begin{array}{l}\tilde{y} \\
\tilde{0}\end{array}$ & $\begin{array}{l}\infty \\
0 \\
0\end{array}$ & : \\
\hline 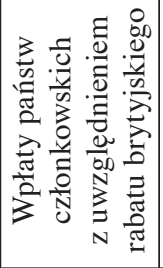 & 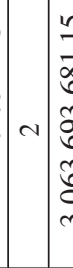 & 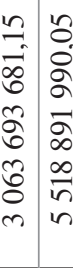 & 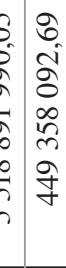 & 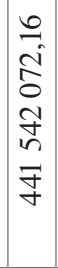 & 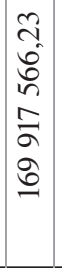 & 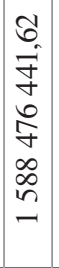 & 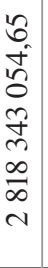 & 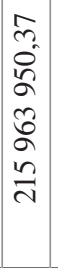 & 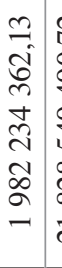 & 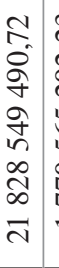 & 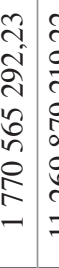 & 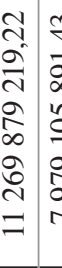 & 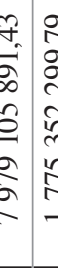 & 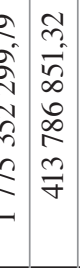 & 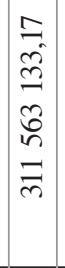 & 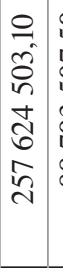 & $\begin{array}{l}0 \\
n \\
5 \\
0 \\
n \\
2 \\
2 \\
\infty \\
\infty\end{array}$ \\
\hline 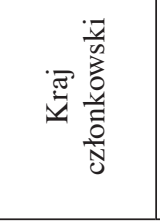 & & 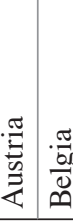 & 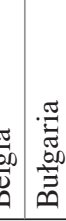 & 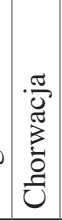 & & & & 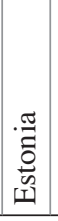 & 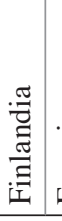 & 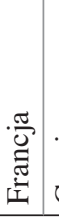 & & & & 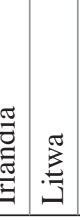 & 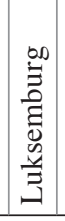 & & \\
\hline
\end{tabular}




\begin{tabular}{|c|c|c|c|c|c|c|c|c|c|c|c|c|}
\hline 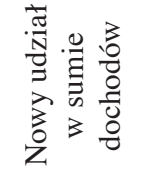 & $\sim$ & $\begin{array}{l}m \\
\tilde{n} \\
\tilde{n}\end{array}$ & $\begin{array}{l}8 \\
\text { m. }\end{array}$ & 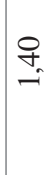 & $\stackrel{2}{\mathrm{n}}$ & $\begin{array}{c}\tilde{b} \\
0 \\
0\end{array}$ & $\begin{array}{c}m \\
\tilde{0} \\
0\end{array}$ & $\frac{尺}{m}$ & $\begin{array}{c}\infty \\
\infty \\
0\end{array}$ & 1 & $\begin{array}{l}\mathcal{1} \\
\infty \\
\mathfrak{I}\end{array} \mid$ & $\begin{array}{l}8 \\
8 \\
8 \\
8\end{array}$ \\
\hline 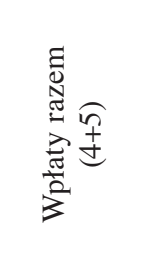 & 0 & $\begin{array}{l}\sigma \\
0 \\
\tilde{0} \\
0 \\
0 \\
\infty \\
\infty \\
\infty \\
\infty \\
\text { m. }\end{array}$ & 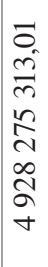 & 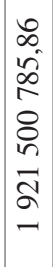 & $\begin{array}{l}0 \\
2 \\
2 \\
2 \\
\infty \\
0 \\
2 \\
n \\
1 \\
-1\end{array}$ & $\begin{array}{l}0 \\
2 \\
0 \\
b \\
0 \\
1 \\
\delta \\
0 \\
n \\
\infty \\
\infty\end{array}$ & 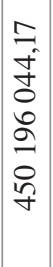 & $\begin{array}{l}n \\
n \\
n \\
n \\
n \\
7 \\
7 \\
8 \\
0 \\
n\end{array}$ & $\begin{array}{l}n \\
n \\
+ \\
i n \\
n \\
\infty \\
2 \\
2 \\
\text { a } \\
-\end{array}$ & 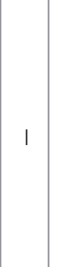 & $\begin{array}{l}2 \\
2 \\
n \\
\infty \\
n \\
= \\
\infty \\
n \\
n \\
=\end{array}$ & 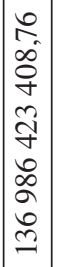 \\
\hline 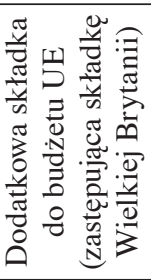 & $n$ & 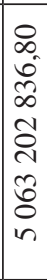 & 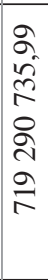 & 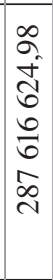 & 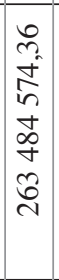 & 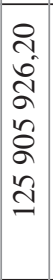 & $\begin{array}{l}\hat{N} \\
\dot{0} \\
0 \\
2 \\
\hat{i} \\
\tilde{0}\end{array}$ & 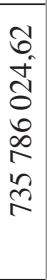 & 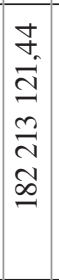 & 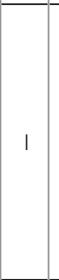 & 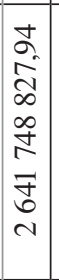 & 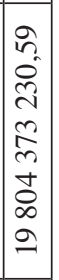 \\
\hline 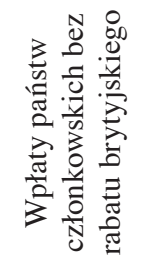 & $\nabla$ & 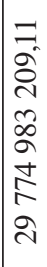 & 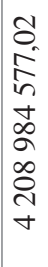 & $\begin{array}{l}\infty \\
\infty \\
0 \\
0 \\
0 \\
\infty \\
\infty \\
\infty \\
\infty \\
0 \\
-1\end{array}$ & 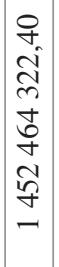 & 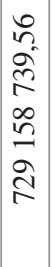 & 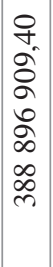 & 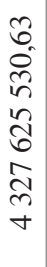 & 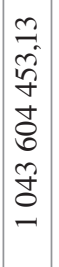 & 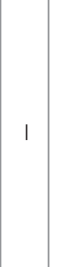 & 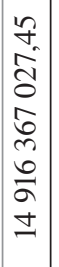 & 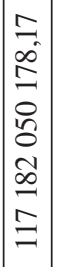 \\
\hline 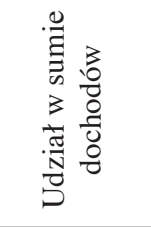 & $m$ & $\stackrel{=}{\vec{N}}$ & $\frac{n}{m}$ & $\stackrel{\overbrace{}}{=}$ & $\stackrel{g}{\theta_{-}}$ & $\begin{array}{l}n \\
n \\
0 \\
0\end{array}$ & ָे & $\begin{array}{l}\infty \\
0 \\
\dot{r}^{2}\end{array}$ & $\frac{\infty}{0}$ & $\begin{array}{l}\Omega \\
\check{\beth}\end{array}$ & さ્ & $\begin{array}{l}8 \\
8 \\
8 \\
8\end{array}$ \\
\hline 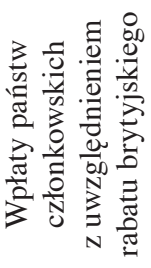 & N & 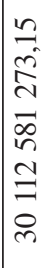 & 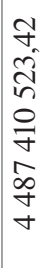 & 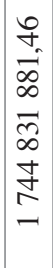 & \begin{tabular}{l}
+ \\
$\infty$ \\
0 \\
0 \\
0 \\
0 \\
0 \\
\multirow{2}{+}{} \\
$\dot{n}$ \\
$i n$ \\
-1
\end{tabular} & 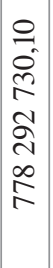 & 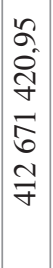 & 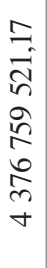 & 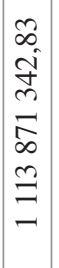 & 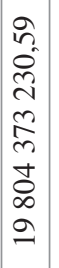 & $\begin{array}{l}n \\
2 \\
b \\
0 \\
\hat{2} \\
2 \\
2 \\
n \\
n\end{array}$ & 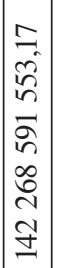 \\
\hline 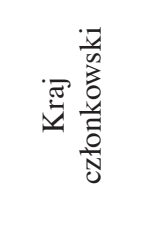 & - & 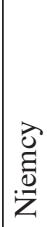 & $\frac{\pi}{\frac{\pi}{0}}$ & 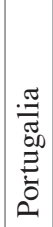 & 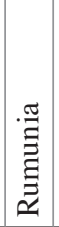 & 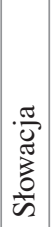 & 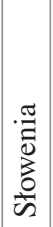 & 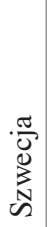 & $\frac{2}{3}$ & 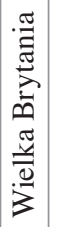 & $\mid \begin{array}{c}\vec{z} \\
0 \\
0 \\
\dot{z}\end{array}$ & $\underset{\Xi}{\Xi}$ \\
\hline
\end{tabular}


W efekcie należałoby wzmocnić funkcjonowanie Europejskiego Mechanizmu Stabilności i w przyszłości przekształcić go w Europejski Fundusz Walutowy (European Monetary Fund).

Idea Europejskiego Funduszu Walutowego (EFW) pojawiła się w opracowaniach naukowców Instytutu Jacquesa Delorsa w 2015 i 2016 r. [Enderlein i Haas 2015, s. 9-10; Brinke, Enderlein i Haas 2016, s. 15], w których proponowano również znaną już ideę uwspólnotowienia części długu publicznego państw strefy euro w zamian za stopniową rezygnację z pewnych prerogatyw dotyczących polityki budżetowej ${ }^{3}$. EFW zostałby utworzony z Europejskiego Mechanizmu Stabilności, przy czym byłby instrumentem szybkiego reagowania i przekazywania krótkoterminowych środków pomocowych w postaci pożyczki w sytuacji nagłego i drastycznego pogorszenia się sytuacji finansowo-gospodarczej danego państwa.

Dodatkowo przedstawiono propozycję europejskiego budżetu inwestycyjnego, z którego środki byłyby przekazywane jako forma wsparcia do państw dotkniętych nagłymi, nieprzewidzianymi wstrząsami (wynikającymi np. z katastrof naturalnych lub przybycia dużej liczby uchodźców) bądź realizujących reformy strukturalne. H. Enderlein i J. Haas [2015, s. 7-10] uważają, że na fundusz złożyłyby się środki pochodzące $\mathrm{z}$ nowego podatku europejskiego, jednak sugerowane rozwiązanie wydaje się tylko teoretyczne wobec trudności państw członkowskich UE z konsolidacją finansów publicznych. Zadaniem budżetu, czy raczej europejskiego funduszu inwestycyjnego, byłoby przekazywanie pieniędzy na działania inwestycyjne państw w sytuacji, gdy ciężar podjętych reform powoduje istotne ograniczenia budżetowe, które najczęściej przyjmują formę redukcji wydatków inwestycyjnych.

A. Banerji i współautorzy [2015, s. 30-34], włączając się w powyższą dyskusję, precyzują jednak, że chodziłoby raczej o zmianę zasad działania funduszy strukturalnych i inwestycyjnych w obrębie budżetu UE, który musiałby zostać zwiększony. Przekazywanie pieniędzy odbywałoby się poprzez umowy między państwami członkowskimi a Komisją Europejską dotyczące realizacji reform społeczno-gospodarczych. W razie niepowodzenia zamierzonych projektów przekazywanie funduszy unijnych byłoby zawieszone.

Zasugerowano dodatkowo, że w takiej sytuacji konieczna stałaby się silniejsza demokratyczna legitymizacja strefy euro. $Z$ tego powodu należałoby powołać europejskiego ministra finansów będącego pod bezpośrednią demokratyczną kontrolą parlamentów krajowych i Parlamentu Europejskiego. Europejski minister finansów, wybierany kwalifikowaną większością głosów przez Radę Europejską za zgodą przewodniczącego Komisji Europejskiej, byłby równocześnie wiceprzewodni-

${ }^{3} \mathrm{~W}$ zależności od wysokości pożyczonej sumy wymogi dotyczyłyby zobowiązania się danego państwa do prezentacji konkretnego zestawu reform uzgodnionego z władzami EFW, poprzez zastosowanie się do rekomendacji EFW odnośnie do projektu budżetu krajowego aż do możliwego weta ze strony EFW dotyczącego projektu budżetu państwa. 
czącym Komisji Europejskiej i przewodniczącym Eurogrupy. Minister stałby na czele Europejskiego Funduszu Walutowego, zarządzałby europejskim budżetem inwestycyjnym i nadzorowałby koordynację polityki gospodarczej i fiskalnej państw strefy euro [Enderlein i Haas 2015, s. 7-10; Brinke, Enderlein i Haas 2016, s. 15].

E. Rubio [2016, s. 7-9] podkreśla, że od czasu prezentacji raportu H. Van Rompuya w 2012 r. [Van Rompuy 2012] pomysł, że strefa euro potrzebuje zdolności fiskalnej w absorpcji szoków asymetrycznych, jest coraz częściej podnoszony. Najczęściej wspomina się o następujących propozycjach:

- utworzenie specjalnego funduszu ubezpieczeniowego na wypadek niekorzystnej sytuacji makroekonomicznej ze składkami państw członkowskich obliczanymi na podstawie luki popytowej,

- stabilizacja dochodów gospodarstw domowych bezpośrednio przez stworzenie systemu, w którym część składki na ubezpieczenie od utraty pracy byłaby wpłacana do europejskiego funduszu, który zapewni podstawowe ubezpieczenia od bezrobocia (do 12 miesięcy),

- stworzenie systemu reasekuracji dla krajowego ubezpieczenia od bezrobocia finansowanego z regularnych składek krajowych systemów i aktywnego w sytuacji, gdy stopa bezrobocia przekroczy określony poziom.

E. Rubio [2016] zaznacza jednak, że nie wspomina się, żeby budżet strefy euro przekraczał 1-2\% DNB, stąd można podać w wątpliwość jego znaczenie dla stabilizowania całej strefy. Alternatywnym rozwiązaniem mogą stać się pożyczki zabezpieczone gwarancjami budżetu strefy euro, a zatem jest to koncepcja zbliżona do formatu Europejskiego Funduszu Walutowego, jak również obecnie funkcjonującego Europejskiego Mechanizmu Stabilności.

Przedstawione rozwiązania łączą w sobie nie tylko dotychczasowe procedury przyjęte dla Europejskiego Mechanizmu Stabilności, ale także w dużej mierze wykorzystywane są w nich zapisy rozporządzeń z 2011 i 2013 r. (tzw. sześcioboku i dwupaku). Ze względu na brak szczegółów trudno ocenić niniejsze propozycje jako istotnie poprawiające działania obecnych mechanizmów i formuł. Wyraźnie jednak widać, że odnoszą się przede wszystkim do państw strefy euro.

\section{Modele integracji europejskiej wobec bieżących wyzwań politycznych, społecznych i gospodarczych i możliwe scenariusze zmian w strukturze budżetu Unii Europejskiej}

W marcu 2017 r. pojawiły się kolejne, wyraźne sygnały dotyczące koniecznych zmian w Unii Europejskiej będących odpowiedzią na wspomniane zagrożenia, a zarazem ruchy dezintegracyjne. Pierwszym elementem stała się Biała księga [2017] Komisji Europejskiej. Zawarte w niej warianty dotyczące przyszłości UE są 
wstępem do pogłębionej debaty, dlatego należy je traktować jako przykłady, które będą podlegać dalszej modyfikacji, zwłaszcza że w wielu miejscach proponowane rozwiązania nakładają się na siebie (tabele 2 i 3).

W pierwszym scenariuszu jest mowa o kontynuacji założeń Komisji Europejskiej [Juncker 2014] oraz deklaracji z Bratysławy [2016], czyli dalsze wzmacnianie gospodarki innowacyjnej, sprzyjającej wzrostowi zatrudnienia i inwestycjom w infrastrukturę transportową, energetyczną i telekomunikacyjną, przyczyniające się do rozwoju jednolitego rynku wewnętrznego (działania w kierunku unii energetycznej i połączonego rynku cyfrowego). Wzmocniony zostanie nadzór dotyczący finansów publicznych i rynku kapitałowego. Polityka zewnętrzna nadal będzie domeną państw członkowskich, przewiduje się jednak wspólne działania (współpracę w zakresie obronności i zwalczania terroryzmu, intensyfikację umów handlowych), jak też istotne poparcie dla funkcjonowania Europejskiej Straży Granicznej i Przybrzeżnej. Polityka podatkowa nadal pozostaje w gestii państw członkowskich, jednak pogłębiają one współpracę dotyczącą przeciwdziałania ucieczce przed podatkami oraz zwalczania prania brudnych pieniędzy, co nadal będzie polegać na wymianie informacji i przyjmowaniu unijnych aktów prawnych.

W drugiej opcji sprawy bezpieczeństwa i obronności pozostaną domeną krajową, natomiast główny nacisk zostanie położony na swobodę przepływu towarów i kapitału przy braku gwarancji dla wspólnego działania w zakresie swobody przepływu osób i usług. Oznacza to, że państwa członkowskie będą swobodnie podchodzić do regulowania kwestii socjalnych, podatkowych, ochrony konsumenta i ochrony środowiska. A zatem uwaga zostanie zwrócona na własne interesy, być może kosztem większych barier dla podmiotów zewnętrznych. W takich sytuacjach istnieje prawdopodobieństwo stosowania uzgodnień dwustronnych, a więc zaprzeczających szerszej integracji, a także częstszych kontroli na granicach wewnętrznych Unii.

Trzeci wariant zakłada szersze stosowanie wzmocnionej współpracy w grupie państw, dotyczącej np. obronności, opodatkowania, innowacyjności przedsiębiorstw, spraw społecznych czy bezpieczeństwa wewnętrznego. Jeżeli w sprawach obrony zostaną utrzymane dotychczasowe uregulowania prawne, to pogłębiona kooperacja będzie polegać na wspólnych działaniach na polu badawczym, przemysłowym i organizacji wspólnych misji wojskowych. O współpracy można mówić również w sprawach bezpieczeństwa wewnętrznego, czyli w odniesieniu do wspólnych akcji służb policyjnych i wywiadowczych, wymiany informacji między nimi, położenia nacisku na walkę z przestępczością zorganizowaną, nadużyciami finansowymi czy praniem brudnych pieniędzy. Kooperacja w zakresie podatków i spraw społecznych może dotyczyć w najbliższej przyszłości przede wszystkim podatku dochodowego od osób prawnych (zwłaszcza opodatkowania przedsiębiorstw ponadnarodowych), podatku od transakcji finansowych czy ochrony pracowników. 
Tabela 2. Warianty struktury wieloletnich ram finansowych po 2020 r. na przykładzie perspektywy finansowej na lata 2014-2020 (w mln EUR)

\begin{tabular}{|c|c|c|c|c|c|}
\hline Specyfikacja & Wariant 1 & Wariant 2 & Wariant 3 & Wariant 4 & Wariant 5 \\
\hline $\begin{array}{l}\text { Konkurencyjność na rzecz } \\
\text { wzrostu i zatrudnienia, } \\
\text { w tym: }\end{array}$ & 142130,00 & 43092,85 & 142130,00 & 142130,00 & 142130,00 \\
\hline $\begin{array}{c}\text { - systemy europejskiej } \\
\text { nawigacji satelitarnej } \\
\text { (EGNOS i Galileo) }\end{array}$ & 7071,73 & 7071,73 & 7071,73 & 7071,73 & 7071,73 \\
\hline $\begin{array}{l}\text { - europejski program } \\
\text { obserwacji Ziemi } \\
\text { (Copernicus) }\end{array}$ & 4291,48 & 4291,48 & 4291,48 & 4291,48 & 4291,48 \\
\hline $\begin{array}{l}\text { - bezpieczeństwo jądrowe } \\
\text { i likwidacja elektrowni } \\
\text { atomowych }\end{array}$ & 1643,09 & & 1643,09 & 1643,09 & 1643,09 \\
\hline $\begin{array}{l}\text { - międzynarodowy eks- } \\
\text { perymentalny reaktor } \\
\text { termonuklearny (ITER) }\end{array}$ & 2985,62 & 2985,62 & 2985,62 & 2985,62 & 2985,62 \\
\hline - horyzont 2020 & 79401,83 & - & 79401,83 & 79401,83 & 79401,83 \\
\hline $\begin{array}{l}\text { - konkurencyjność na } \\
\text { rzecz przedsiębiorstw } \\
\text { oraz małych i śred- } \\
\text { nich przedsiębiorstw } \\
\text { (COSME) }\end{array}$ & 2298,24 & - & 2298,24 & 2298,24 & 2298,24 \\
\hline $\begin{array}{l}\text { - edukacja, kształcenie, } \\
\text { młodzież i sport } \\
\text { (Erasmus+) }\end{array}$ & 14774,52 & - & 14774,52 & 14774,52 & 14774,52 \\
\hline $\begin{array}{l}\text { - zatrudnienie i innowa- } \\
\text { cje społeczne }\end{array}$ & 919,47 & - & 919,47 & 919,47 & 919,47 \\
\hline $\begin{array}{l}\text { - cła, podatki i zwalczanie } \\
\text { nadużyć finansowych }\end{array}$ & 908,01 & 908,01 & 908,01 & 908,01 & 908,01 \\
\hline $\begin{array}{l}\text { - mechanizm „Łącząc } \\
\text { Europę” }\end{array}$ & 21936,76 & 21936,76 & 21936,76 & 21936,76 & 21936,76 \\
\hline - energia & 5850,08 & 5850,08 & 5850,08 & 5850,08 & 5850,08 \\
\hline - transport & 14945,08 & 14945,08 & 14945,08 & 14945,08 & 14945,08 \\
\hline $\begin{array}{l}\text { - technologie informa- } \\
\text { cyjne i komunikacyjne }\end{array}$ & 1141,60 & 1141,60 & 1141,60 & 1141,60 & 1141,60 \\
\hline $\begin{array}{l}\text { Spójność ekonomiczna, } \\
\text { społeczna i terytorialna, } \\
\text { w tym: }\end{array}$ & 366791,00 & - & 366791,00 & - & 366791,00 \\
\hline $\begin{array}{l}\text { - inicjatywa na rzecz } \\
\text { zatrudnienia młodzieży }\end{array}$ & 3211,22 & - & 3211,22 & - & 3211,22 \\
\hline
\end{tabular}


cd. tabeli 2

\begin{tabular}{|c|c|c|c|c|c|}
\hline Specyfikacja & Wariant 1 & Wariant 2 & Wariant 3 & Wariant 4 & Wariant 5 \\
\hline $\begin{array}{l}\text { - konwergencja regio- } \\
\text { nalna (regiony najmniej } \\
\text { rozwinięte) }\end{array}$ & 185374,42 & - & 185374,42 & - & 185374,42 \\
\hline - regiony przejściowe & 35701,31 & - & 35701,31 & - & 35701,31 \\
\hline $\begin{array}{l}\text { - konkurencyjność } \\
\text { (regiony najbardziej } \\
\text { rozwinięte) }\end{array}$ & 55780,14 & - & 55780,14 & - & 55780,14 \\
\hline $\begin{array}{l}\text { - europejska współpraca } \\
\text { terytorialna }\end{array}$ & 10228,81 & - & 10228,81 & - & 10228,81 \\
\hline - fundusz spójności & 74928,36 & - & 74928,36 & - & 74928,36 \\
\hline $\begin{array}{l}\text { - regiony ultrapery- } \\
\text { feryjne i o słabym } \\
\text { zaludnieniu }\end{array}$ & 1562,99 & - & 1562,99 & - & 1562,99 \\
\hline $\begin{array}{l}\text { Trwały wzrost - zasoby } \\
\text { naturalne, w tym: }\end{array}$ & 420034,00 & - & 420034,00 & - & 420034,00 \\
\hline $\begin{array}{l}\text { - Europejski Fundusz } \\
\text { Rolniczy Gwarancji }\end{array}$ & 312735,00 & - & 312735,00 & - & 312735,00 \\
\hline $\begin{array}{l}\text { - Europejski Fundusz } \\
\text { Rolny na rzecz Rozwoju } \\
\text { Obszarów Wiejskich }\end{array}$ & 95577,05 & - & 95577,05 & - & 95577,05 \\
\hline $\begin{array}{l}\text { - Europejski Fundusz } \\
\text { Morski i Rybacki }\end{array}$ & 7404,84 & - & 7404,84 & - & 7404,84 \\
\hline $\begin{array}{l}\text { - środowisko i działania } \\
\text { w dziedzinie klimatu } \\
\text { (LIFE) }\end{array}$ & 3456,66 & - & 3456,66 & - & 3456,66 \\
\hline $\begin{array}{l}\text { Bezpieczeństwo i obywa- } \\
\text { telstwo, w tym: }\end{array}$ & 17725,00 & 3764,23 & 17725,00 & 7040,32 & 17725,00 \\
\hline $\begin{array}{l}\text { - fundusz migracyjny } \\
\text { i azylowy }\end{array}$ & 3137,43 & - & 3 137,43 & 3 137,43 & 3137,43 \\
\hline $\begin{array}{l}\text { - fundusz bezpieczeństwa } \\
\text { wewnętrznego }\end{array}$ & 3764,23 & 3764,23 & 3764,23 & 3764,23 & 3764,23 \\
\hline - systemy informacyjne & 138,66 & - & 138,66 & 138,66 & 138,66 \\
\hline - sprawiedliwość & 377,60 & - & 377,60 & - & 377,60 \\
\hline $\begin{array}{l}\text { - prawa, równość i oby- } \\
\text { watelstwo }\end{array}$ & 439,47 & - & 439,47 & - & 439,47 \\
\hline - ochrona cywilna & 223,78 & - & 223,78 & - & 223,78 \\
\hline - Europa dla obywateli & 185,47 & - & 185,47 & - & 185,47 \\
\hline - żywność i pasze & 1891,94 & - & 1891,94 & - & 1891,94 \\
\hline
\end{tabular}


cd. tabeli 2

\begin{tabular}{|c|c|c|c|c|c|}
\hline Specyfikacja & Wariant 1 & Wariant 2 & Wariant 3 & Wariant 4 & Wariant 5 \\
\hline - zdrowie publiczne & 449,39 & - & 449,39 & - & 449,39 \\
\hline - ochrona konsumentów & 188,83 & - & 188,83 & - & 188,83 \\
\hline - kreatywna Europa & 1462,72 & - & 1462,72 & - & 1462,72 \\
\hline $\begin{array}{l}\text { Globalny wymiar Europy, } \\
\text { w tym: }\end{array}$ & 66262,00 & 57512,70 & 64504,37 & 66262,00 & 66262,00 \\
\hline $\begin{array}{l}\text { - instrument pomocy } \\
\text { przedakcesyjnej }\end{array}$ & 11698,67 & 11698,67 & 11698,67 & 11698,67 & 11698,67 \\
\hline $\begin{array}{l}\text { - europejski instrument } \\
\text { sąsiedztwa }\end{array}$ & 15432,63 & 15432,63 & 15432,63 & 15432,63 & 15432,63 \\
\hline $\begin{array}{l}\text { - europejski instrument } \\
\text { na rzecz demokracji } \\
\text { i praw człowieka }\end{array}$ & 1332,75 & 1332,75 & 1332,75 & 1332,75 & 1332,75 \\
\hline - instrument stabilności & 2338,72 & 2338,72 & 2338,72 & 2338,72 & 2338,72 \\
\hline $\begin{array}{l}\text { - wspólna polityka } \\
\text { zagraniczna i bezpie- } \\
\text { czeństwo }\end{array}$ & 2338,72 & 2338,72 & 2338,72 & 2338,72 & 2338,72 \\
\hline - instrument partnerstwa & 954,77 & 954,77 & 954,77 & 954,77 & 954,77 \\
\hline $\begin{array}{l}\text { - instrument współpracy } \\
\text { i rozwoju }\end{array}$ & 19661,64 & 19661,64 & 19661,64 & 19661,64 & 19661,64 \\
\hline - pomoc humanitarna & 6621,70 & - & 6621,70 & 6621,70 & 6621,70 \\
\hline $\begin{array}{l}\text { - mechanizm ochrony } \\
\text { cywilnej }\end{array}$ & 144,65 & - & 144,65 & 144,65 & 144,65 \\
\hline $\begin{array}{l}\text { - instrument współpracy } \\
\text { w zakresie bezpieczeń- } \\
\text { stwa jądrowego }\end{array}$ & 225,32 & - & 225,32 & 225,32 & 225,32 \\
\hline - pomoc makrofinansowa & 564,56 & - & - & 564,56 & 564,56 \\
\hline $\begin{array}{l}\text { - gwarancje UE z tytułu } \\
\text { udzielonych pożyczek }\end{array}$ & 1193,07 & - & - & 1193,07 & 1193,07 \\
\hline Administracja & 69584,00 & 69584,00 & 69584,00 & 69584,00 & 69584,00 \\
\hline Kompensaty & 29,00 & - & - & - & - \\
\hline Suma & 1082555,00 & 173953,78 & 1080768,37 & 285016,32 & 1082526,00 \\
\hline
\end{tabular}

Uwaga: czcionką pogrubioną zaznaczono obszary, na które mogą zostać istotnie zwiększone środki, natomiast kursywą - możliwe znaczne ograniczenie funduszy.

Źródło: opracowanie własne na podstawie danych Komisji Europejskiej, http://ec.europa.eu/budget/figures/interactive/index_en.cfm (data dostępu: 21.03.2017). 


\begin{tabular}{|c|c|c|c|}
\hline 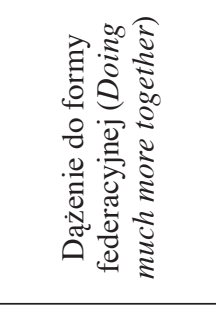 & 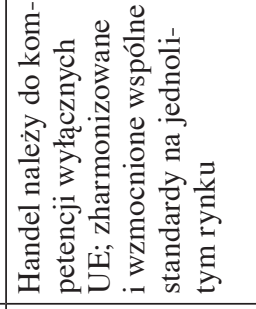 & 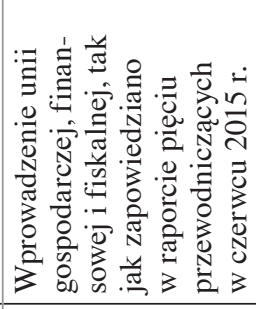 & 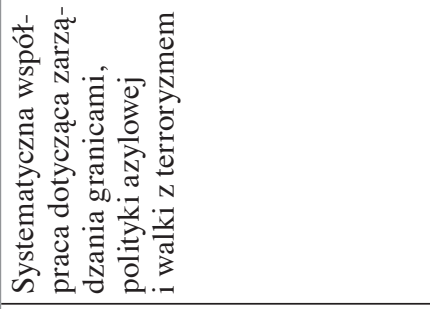 \\
\hline 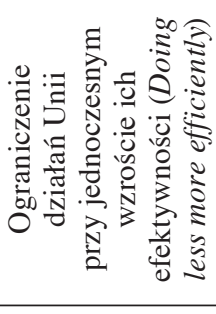 & 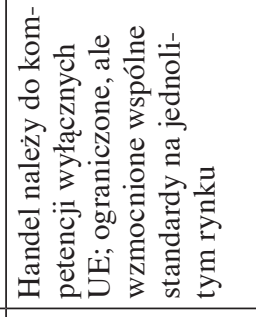 & 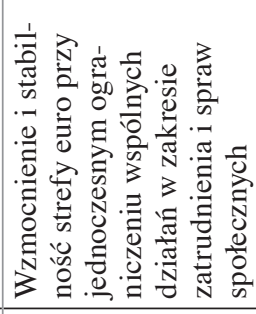 & 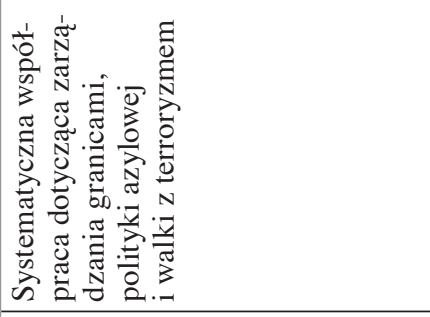 \\
\hline 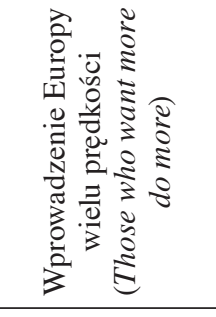 & 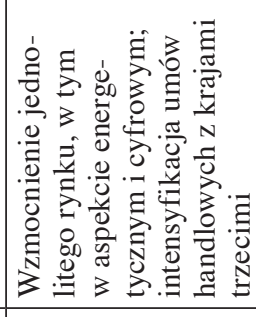 & 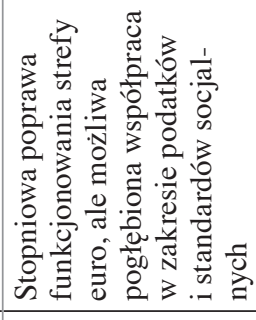 & 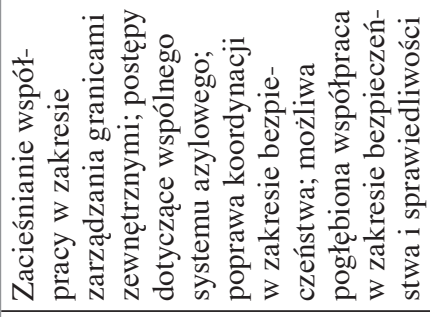 \\
\hline 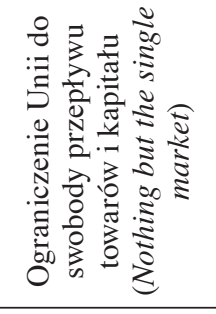 & 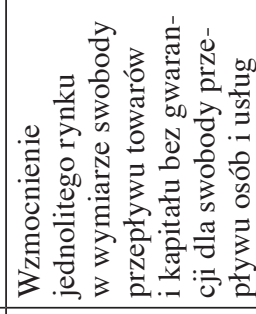 & 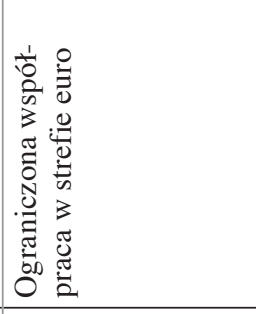 & 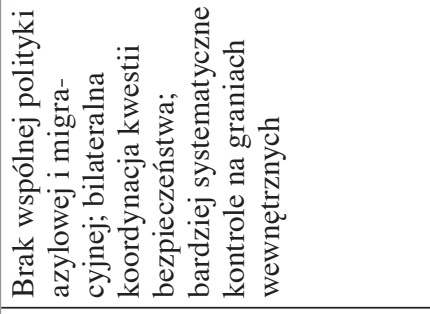 \\
\hline 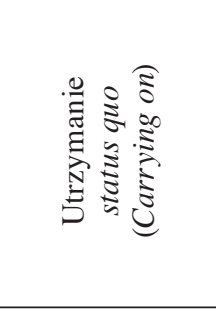 & 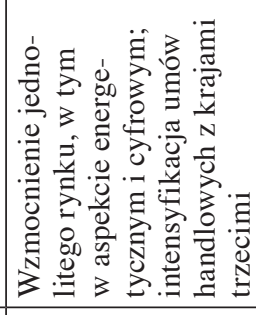 & 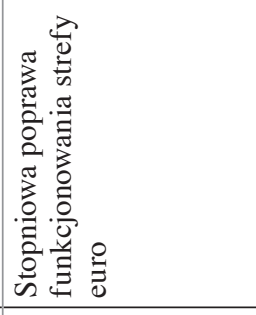 & 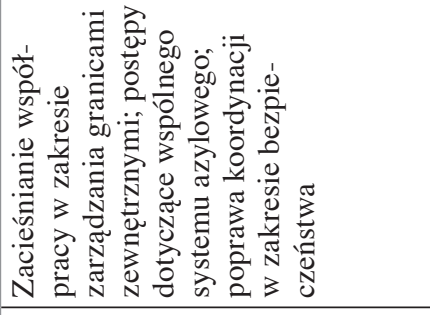 \\
\hline 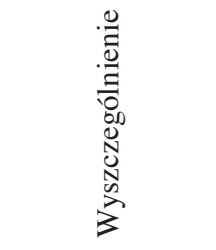 & 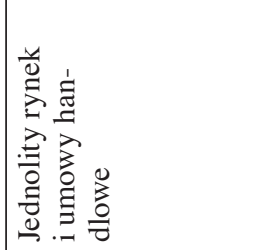 & 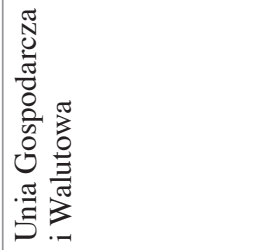 & 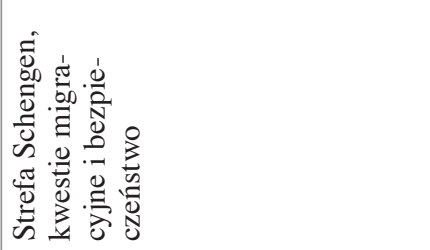 \\
\hline
\end{tabular}




\begin{tabular}{|c|c|c|}
\hline 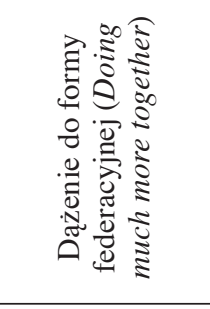 & 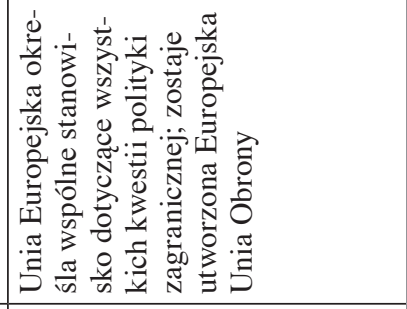 & 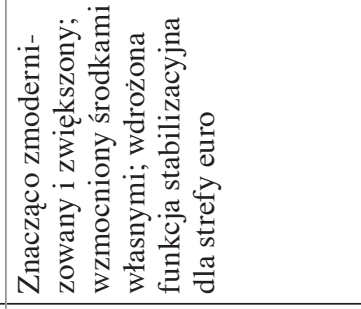 \\
\hline 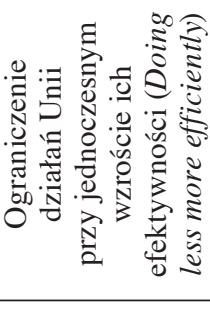 & 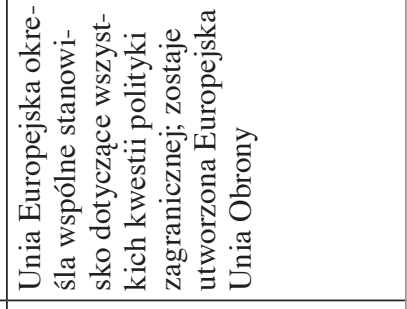 & 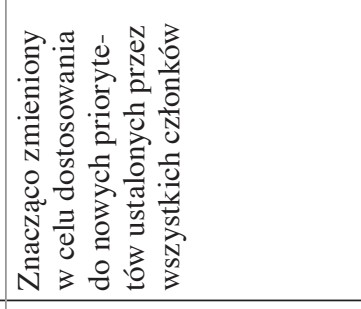 \\
\hline 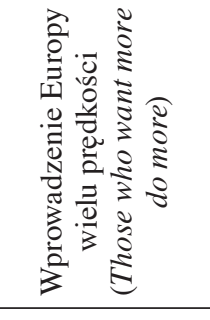 & 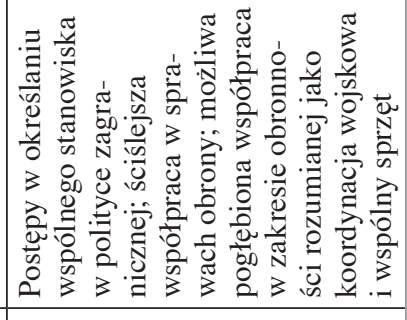 & 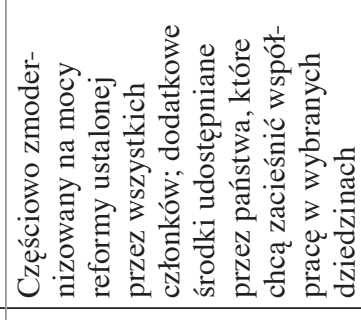 \\
\hline 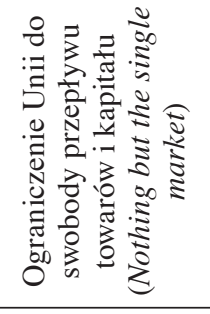 & 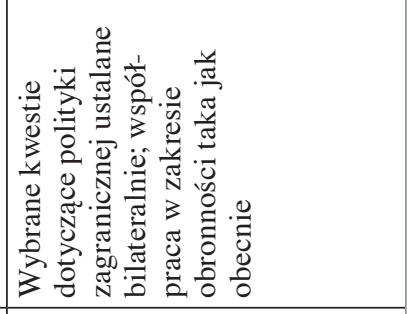 & 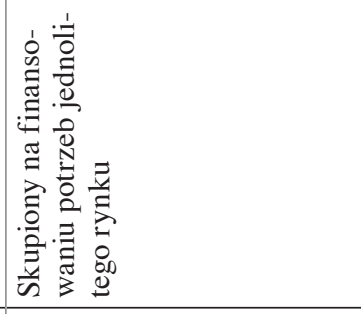 \\
\hline 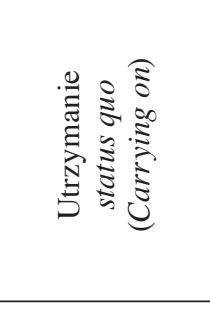 & 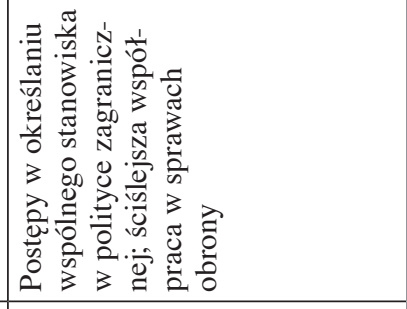 & 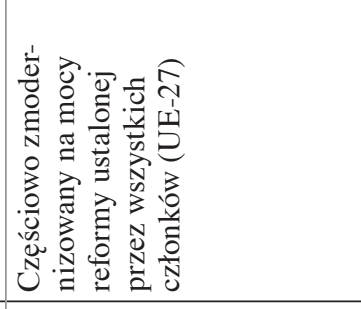 \\
\hline 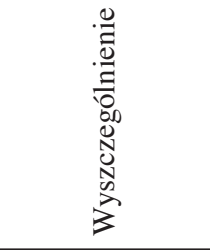 & 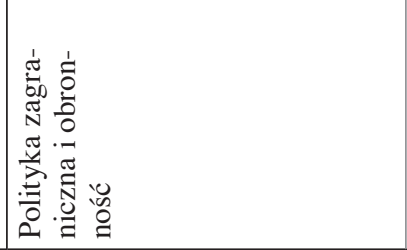 & 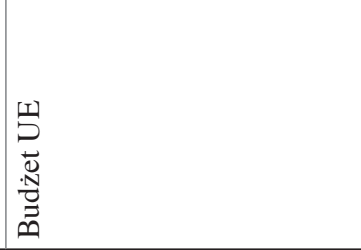 \\
\hline
\end{tabular}




\begin{tabular}{|c|c|}
\hline 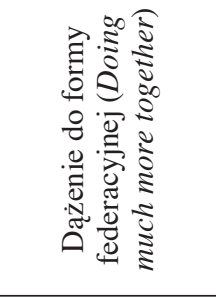 & 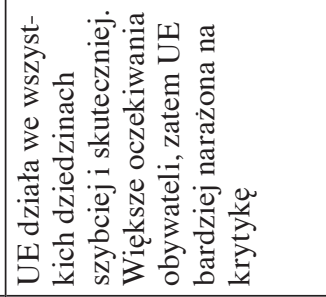 \\
\hline 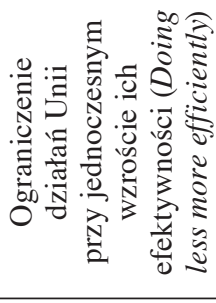 & 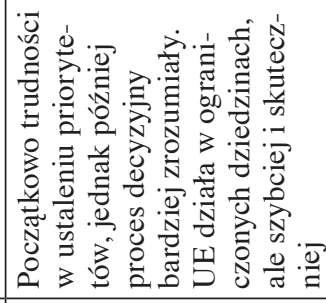 \\
\hline 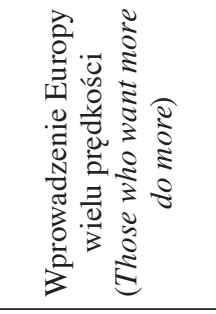 & 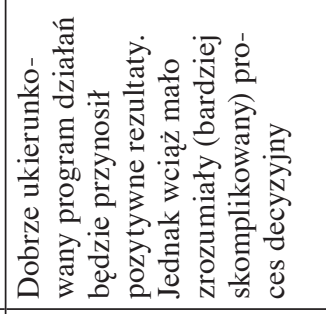 \\
\hline 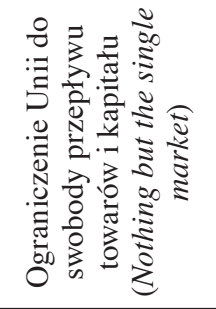 & 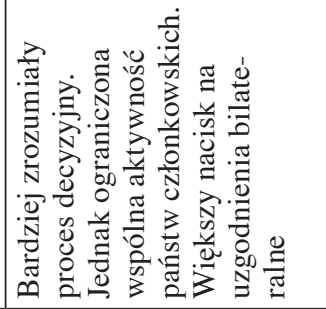 \\
\hline 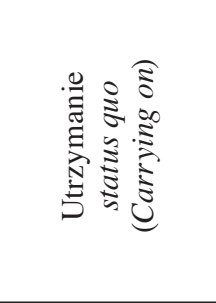 & 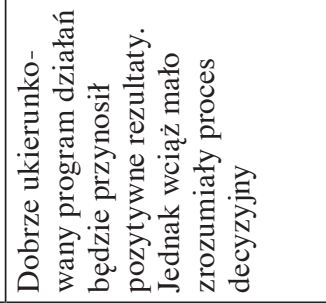 \\
\hline 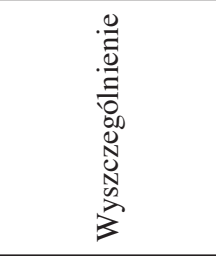 & 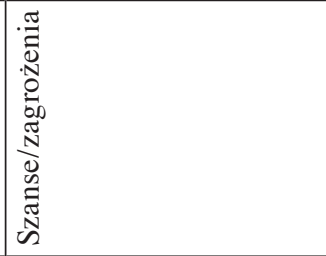 \\
\hline
\end{tabular}


Wariant czwarty został nakreślony bardzo nieprecyzyjnie, co daje możliwość jego rozwinięcia w wielu kierunkach. Podkreślono przede wszystkim rozwój Unii Europejskiej w kierunku badań i rozwoju, cyfryzacji gospodarki, ochrony środowiska (ale tylko w aspekcie dekarbonizacji), handlu, obrony granic (tzw. wspólne zdolności obronne) i bezpieczeństwa wewnętrznego (kooperacja służb policyjnych i wywiadowczych, walka z terroryzmem). Sprawami ochrony granic zewnętrznych będzie się zajmować wyłącznie Europejska Straż Graniczna i Przybrzeżna. Ograniczony zostanie udział wspólnotowy w zakresie polityki regionalnej, kwestii dotyczących zdrowia publicznego, polityki zatrudnienia czy spraw społecznych.

Dwie ostatnie kwestie będą realizowane tylko dla potrzeb funkcjonowania jednolitego rynku wewnętrznego, zatem należy się spodziewać, że chodzi o zapewnienie takich samych standardów dla osób pracujących, kształcących się czy objętych polityką społeczną poza granicami kraju pochodzenia. Natomiast dotychczas realizowana strategia zmniejszania różnic między regionami i państwami w zakresie poziomu życia, zmniejszania bezrobocia, podnoszenia kwalifikacji, kształcenia i walki z wykluczeniem społecznym stanie się domeną wyłącznie państwową. Wydaje się, że taki scenariusz nie jest możliwy do realizacji w ciągu najbliższych dziesięciu lat, biorąc pod uwagę strategię Europa 2020, w której sprawy społeczne określone zostały jako priorytety. Nie ulega wątpliwości, że współpraca państw strefy euro będzie podlegać intensyfikacji.

Wariant piąty nie jest natomiast możliwy do całościowego wprowadzenia w okresie siedmiu lat po zakończeniu obecnych wieloletnich ram finansowych. Zakłada on bowiem pełne przejęcie uprawnień przez UE w zakresie handlu (w przypadku umów z państwami trzecimi konieczna jest zgoda Parlamentu Europejskiego), obronności (powstanie Europejskiej Unii Obrony) i bezpieczeństwa (w tym polityki migracyjnej). Dojdzie do dokończenia budowy w pełni jednolitego rynku wewnętrznego z czterema swobodami, jednolitym rynkiem cyfrowym i wspólnymi regulacjami dotyczącymi rynku energii. Jeszcze większy nacisk zostanie położony na cyfryzację gospodarki. Dojdzie do wzmocnienia współpracy państw strefy euro poprzez przekształcenie obecnego Europejskiego Mechanizmu Stabilizacyjnego we wspomniany już Europejski Fundusz Walutowy.

Na spotkaniu w Wersalu 6 marca 2017 r. przedstawicieli czterech największych gospodarek Unii Europejskiej (z pominięciem Wielkiej Brytanii), tj. kanclerz Niemiec, prezydenta Francji oraz premierów Hiszpanii i Włoch, uznano, że Europa wielu prędkości jest jedynym rozwiązaniem pozwalającym na dalszy rozwój ugrupowania. Podkreślono jednak, że jest to idea otwarta dla wszystkich państw członkowskich, jeżeli uznają, że chcą pogłębionej współpracy w nowych dziedzinach. Idea ta została poparta przez ministrów spraw zagranicznych Francji i Niemiec. 
W deklaracji przyjętej z okazji 60. rocznicy podpisania traktatów rzymskich nie zdecydowano się jednak na wprowadzenie określenia Europy różnych prędkości z powodu sprzeciwu niektórych krajów obawiających się podziałów w obrębie Unii Europejskiej. Obawy dotyczą przede wszystkim powstania Europy państw rdzenia, czyli budowania swoistego centrum (np. w obrębie strefy euro) z większą mocą decyzyjną, oraz peryferii [Barcz 2015, s. 240-248; Balcer i Zerka 2017, s. 11-12]. Choć taki układ nie oddzielałby państw peryferyjnych od „twardego jądra”, istniałoby jednak zagrożenie coraz szybszego oddalania się jednej grupy od drugiej. Nie oznacza to rezygnacji z samej koncepcji, ale należy się spodziewać, że będzie ona realizowana stopniowo przy aprobacie wszystkich członków ${ }^{4} \mathrm{w}$ formie, która została określona przez J. Barcza [2015] jako integracja zróżnicowana, wymagająca nowych rozwiązań w zakresie instytucjonalnym (przykładowo istniejąca już Eurogrupa czy spotkania najwyższych przedstawicieli państw i rządów strefy euro), proceduralnym (podejmowanie decyzji) i finansowym (odrębny budżet), lub w formie określanej jako integracja elastyczna, która rozumiana jest inaczej niż wskazuje to J. Barcz [2015], zakłada bowiem łączenie się państw w różne konfiguracje w zależności od dziedziny bez jednoznacznie określonej grupy wiodącej.

Według Y. Bertonciniego [2017, s. 4] zróżnicowana integracja jest już faktem (strefa euro czy strefa Schengen), mającym swoje umocowanie prawne, należy jednak unikać określenia „Europa wielu prędkości”, które dla części członków może kojarzyć się z pozostawaniem w tyle, pominięciem lub wykluczeniem. W efekcie postęp w celu wspierania nowych wysiłków integracyjnych w Unii Gospodarczej i Walutowej może być związany z utworzeniem budżetu dla strefy euro i równocześnie ze zmianami w strukturze budżetu UE.

Analizując wyżej zaprezentowane dokumenty, stanowiska niektórych państw członkowskich, a także opinię wspomnianych ministrów spraw zagranicznych Francji i Niemiec, J.M. Ayraulta i S. Gabriela, ustaloną dzień po ogłoszeniu Białej księgi, stopniowe wdrażanie Europy wielu prędkości może w siedmioletnim okresie po 2020 r. polegać na ściślejszej współpracy w zakresie (http://franceintheus.org/spip.php?article7998, data dostępu: 25.02.2017):

1) obrony, jednak w finansowym wymiarze ograniczonej do wspólnego pokrywania kosztów administracyjnych (utrzymania unijnych sztabów dowodzenia wojskowego). Przykładowo w marcu 2017 r., w nawiązaniu do orędzia o stanie Unii, ministrowie obrony i spraw zagranicznych podjęli decyzję o utworzeniu stałego dowództwa w celu koordynacji operacji wojskowych w niektórych państwach afrykańskich (Military Planning and Conduct Capability) w ramach Sztabu Wojskowego UE. Celem jest sprawniejsze i skuteczniejsze reagowanie w ramach

${ }^{4}$ Ponadto wynik wyborów we Francji i w Niemczech może także wpłynąć na najbliższą przyszłość integracji. 
misji wojskowych. Ponadto zaplanowano określenie zasad i procedur do rocznego przeglądu w zakresie obronności służącego wymianie doświadczeń, poprawie zdolności bojowych i większej spójności w wydatkowaniu środków krajowych na obronność (http://www.consilium.europa.eu/pl/press/press-releases/2017/03/06-conclusions-security-defence/, data dostępu: 27.03.2017);

2) ochrony granic zewnętrznych i polityki imigracyjnej przez utworzenie wspólnych organów i nadanie im szerokich uprawnień;

3) polityki podatkowej, głównie w aspekcie przeciwdziałania nadużyciom i oszustwom podatkowym, ale także wdrożenie wspólnej skonsolidowanej podstawy opodatkowania osób prawnych i podatku od transakcji finansowych;

4) pogłębionej Unii Gospodarczej i Walutowej z własnym budżetem;

5) współpracy kulturalnej i spraw młodzieży, czyli kształcenia, podnoszenia kwalifikacji i zatrudnienia.

\section{Wnioski}

Biorąc pod uwagę dotychczasowy sprzeciw niektórych państw członkowskich wobec idei ściślejszej integracji finansowej w zakresie podatku europejskiego, emisji euroobligacji, czyli uwspólnotowienia części długu publicznego krajów członkowskich, czy też stałego mechanizmu transferów mających charakter pomocy na wypadek znacznego pogorszenia sytuacji narodowych finansów publicznych, idea federalizmu fiskalnego nie jest możliwa do zrealizowania w krótkim czasie. Nie oznacza to jednak dalszych poszukiwań nowych rozwiązań, które uczyniłyby z finansów Unii Europejskiej system bardziej przejrzysty i zrozumiały dla obywateli. Należy zatem odrzucić również hipotezę o dezintegracji finansowej, ponieważ już zaraz po ogłoszeniu wyników referendum w Wielkiej Brytanii można było zaobserwować wśród polityków europejskich większą zgodność, jeśli chodzi o utrzymanie jedności wśród pozostałych państw członkowskich (przykładem jest wspólna propozycja ministrów spraw zagranicznych Francji i Niemiec). Niezależnie od tego, czy wyrażanie postawy jedności i solidarności w obronie idei, jaką jest Unia Europejska, to tylko zabieg polityczny wynikający z obawy przed dalszymi działaniami separatystycznymi oraz polityką krajów trzecich, m.in. Rosji i Stanów Zjednoczonych, wydaje się, że powinien to być znaczący impuls do stopniowej reformy integracji europejskiej, w tym finansów unijnych.

Państwa członkowskie Unii Europejskiej muszą zmierzyć się obecnie z koniecznością nowego określenia idei integracji, mając na względzie wspomniane zagrożenia i problemy o charakterze lokalnym, narodowym i globalnym zewnętrznym. Redefinicja kierunków wspólnego działania może być szansą wprowadzenia nowych korzystnych rozwiązań dla całego ugrupowania. Nie należy 
jednak zapominać, że dla poszczególnych członków może się to wiązać z narzuceniem odmiennego niż dotychczasowy modelu integracji w postaci tzw. Europy wielu prędkości, który będzie rozwinięciem istniejącej już, ale w ograniczonym zakresie, formuły wzmocnionej współpracy.

\section{Literatura}

Balcer A., Zerka P. [2017], Hard Love, Actually. Polish-German Relations and a 'Multispeed Europe' - a View from Warsaw, Fundacja Warszawski Instytut Studiów Ekonomicznych i Europejskich, WiseEuropa, Warszawa.

Banerji A., Barkbu B., John J., Kinda T., Saksonovs S., Schoelermann H., Wu T. [2015], Building a Better Union: Incentivizing Structural Reforms in the Euro Area, IMF Working Paper 15/201.

Barcz J. [2015], Główne kierunki reformy ustrojowej post-lizbońskiej Unii Europejskiej, Wszechnica IJM, Piaseczno.

Bertoncini Y. [2017], L'intégration différenciée dans l'Union Européenne: une légitimité à géométrie variable, Policy Paper No 186, Notre Europe, Institut Jacques Delors, Paris.

Biała księga w sprawie przyszłości Europy. Refleksje i scenariusze dotyczqce przyszłości UE-27 do 2025 r. [2017], Komisja Europejska, COM(2017)2025, Bruksela, https://doi. org/10.2775/980700.

Brinke A. auf dem, Enderlein H., Haas J. [2016], Why the Eurozone Can't Agree on Convergence and How Structural Reforms Can Help, Policy Paper No 165, Jacques Delors Institut, Berlin.

Budżet Unii Europejskiej na 2016 rok, Dz. Urz. UE 2016, L 48.

Deklaracja z Bratysławy i plan z Bratysławy [2016], Rada Europejska, Bratysława.

Enderlein H., Haas J. [2015], What Would a European Finance Minister Do? A Proposal, Policy Paper No 145, Jacques Delors Institut, Berlin.

Juncker J.C. [2014], Nowy poczq̨tek dla Europy: mój program na rzecz zatrudnienia, wzrostu, sprawiedliwości oraz zmian demokratycznych, Wytyczne polityczne na następną kadencję Komisji Europejskiej, Przemówienie inauguracyjne wygłoszone podczas sesji plenarnej Parlamentu Europejskiego, Strasburg.

Rubio E. [2016], Fédéraliser la zone euro: vers un véritable budget européen?, Policy Paper No 155, Notre Europe, Institut Jacques Delors, Paris.

Van Rompuy H. [2012], Towards a Genuine Economic and Monetary Union, Report by President Herman Van Rompuy in close collaboration with the Presidents of the European Commission, Eurogroup and European Central Bank, Brussels.

\section{The Structure of EU Expenditure after 2020 and Integration Challenges}

(Abstract)

The article presents the latest concepts of integration models with particular attention to financial issues, i.e. the possible directions for spending EU funds after 2020 in view of possible new common economics, social and defense strategies. The reflections are based 
on a scenario approach, where the most important element is determining how realistically fiscal federalism can be introduced in the European Union. It follows from this that the analysis would have a political aspect, meaning possible institutional changes.

Keywords: EU expenditure, multiannual financial framework, European integration, Brexit. 